УДК $621(4.2)$

${ }^{[0000-0001-5287-3733]}$ Г. С. Столяренко, д.m.н., профессор

e-mail: radikal@ukr.net

Черкасский государственный технологический университет

б-р Шевченко, 460, г. Черкассы, 18006, Украина

\title{
ТЕОРЕТИЧЕСКИЕ ОСНОВЫ ПРОЦЕССА ОЗОНИРОВАНИЯ ЖИДКОГО ТОПЛИВА И ИЗУЧЕНИЕ ВЛИЯНИЯ МАЛЫХ ДОЗ ОЗОНА НА РАБОТУ КАРБЮРАТОРНОГО ДВИГАТЕЛЯ ВНУТРЕННЕГО СГОРАНИЯ (ДВС)
}

В работе представлен процесс озонирования жидкого топлива и изучение влияния работьл доз озона на работу двигателя. Приведены механизмы химических прочессов интенсификации сжигания топлива, подавления образования токсичных соединений при дозировании озона. Эксперимантально доказано влияние малых доз озона на процесс сжигания бензина в двигателях внутреннего сгорания. Исходя из результатов исследований названа краткая техническая характеристика двигателя и тормозного стенда. Описаны теоретические основы аналитического контроля проиесса, снижение содержания оксида углерода, влияние озона на содержание сажи в отработавиих газах, изменение режимных факторов при работе двигатели.

Ключевые слова: озонолиз олефиновых углеводородов, подготовка топлива к сжиганию, горение озонированных бензинов.

У статті представлено дослідження процесу озонування рідкого палива і вивчення впливу доз озону на роботу двигуна внутрішнього згоряння при дозуванні окиснювача в повітря, щзо подається в карбюратор $i$ в паливо. Досліджено хімізм процесу газофазного озонолізу. Наведено механізми хімічних прочесів інтенсифікації спалювання палива, придушення утворення токсичних сполук при дозуванні озону. Показано радикально-іонний механізм ланцңюгових реакцій макровпливу окиснювача при його мікродобавках. Проведено експериментальну перевірку впливу малих доз озону на процес спалювання бензину в двигунах внутрішнього згоряння. Дослідження щуодо дозування озону в двигун внутрішнього згоряння проводилися на стендовій установці. Витрати палива двигуном замірялися шляхом прямого визначення зміни маси палива в часі. Витрати повітря, споживаного двигуном внутрішнього згоряння, заміряли за допомогою диференціального манометра. Температуру відпрацьвованих газів вимірювали за допомогою термопари. Описано теоретичні основи аналітичного контролю процесу і отримані результати стосовно зниження вмісту оксиду вуглецю, а також впливу озону на вміст сажі у відпрацьованих газах, зміну режимних факторів при роботі двигуна. Вплив мікродозування озону вивчався при різних режсимах роботи двигуна: на холостому ходу й при малих навантаженнях (до $30 \%$ від номінальної потужності тормозного стенда (генератора)). Схема озонного ініціювання роботи карбюраторного ДВЗ включає дві стадіі: отримання озоно-повітряної суміші і ї̈ використання. Основні результати експериментального вивчення роботи двигуна внутрішнього згоряння при введенні в карбюратор озоно-повітряної суміші показали, щзо при озонуванні спостерігається поліпшення підготовки паливноповітряної суміші до згоряння, забезпечується рівномірність горіння у всьому фронті полум'я. Встановлено, щуо використання озонованого бензину покращує економічність двигуна і підвищує його потужність.

Ключові слова: озоноліз олефінових вуглеводнів, підготовка палива до спалювання, горіння озонованих бензинів.

Способы подачи озона в основной воздушный поток перед карбюратором двигателя $[1,2]$, а также подготовки топлива к сжиганию [3] путем дозирования озона в бензин непосредственно перед подачей последнего на смешение с воздухом можно отнести к методам подавления образования токсичных примесей в отработавших газах на стадии горения. В первом случае это осуществляется за счет газофазного окисления олефиновых углеводородов при изменении окислительной способности дутья, во втором - за счет синтеза кислородсодержащих в жидкой фазе, сжигание которой можно классифицировать как сжигание нетрадиционных видов топлива.

Цель исследования: изучить влияние малых доз озона на работу карбюраторного (C) Г. С. Столяренко, 2019 DOI: $10.24025 / 2306-4412.4 .2019 .185448$
ДВС при дозировании окислителя в воздух, подаваемый в карбюратор, и в топливо.

Химизм процесса газофазного озонолиза. Механизм реакций озонолиза олефиновых углеводородов изучен достаточно подробно, что в принципе даёт возможность теоретически проследить влияние синтезированных промежуточных соединений на процессы, протекающие при горении топливовоздушной смеси. Первичным продуктом в соответствии с механизмом Крите является малозонид [цит. по 4]:<smiles>[R]C=C[R20]O[R]C1OOOC1[R2]</smiles> 
Малозонид нестоек, он быстро распадается, образуя биполярный ион и карбонильное<smiles>[R]C1OOOC1[R]</smiles>

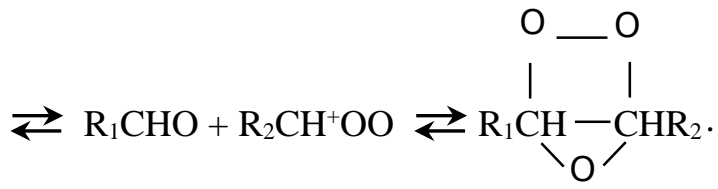

Реакции хемодеструкции озонидов приводят к образованию ряда радикалов:

$$
\begin{aligned}
& \stackrel{\stackrel{\mathrm{O}}{\mathrm{I}} \underset{\mathrm{R}}{\mathrm{C}} \underset{\mathrm{O}^{\prime}}{\mathrm{C}} \mathrm{IHR}_{2}}{\mathrm{O}} \rightarrow \mathrm{RCHO}+\mathrm{R}_{2} \mathrm{CO}^{\circ}+\mathrm{H}_{2} \mathrm{O}(3) \\
& 0 \text { - } 0
\end{aligned}
$$

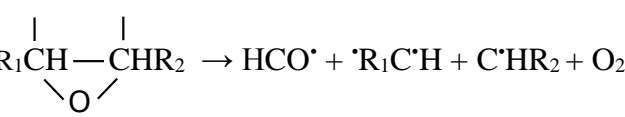

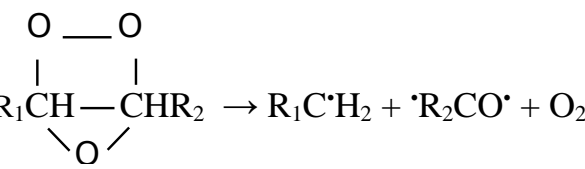

Образующиеся радикалы могут частично вступать в реакции с углеводородами бензина, например, с парафиновыми. При этом возможно образование спиртов, альдегидов, кетонов и эфиров:

$$
\begin{array}{r}
\mathrm{R}_{2} \mathrm{CHOO}^{\circ}+\mathrm{R}_{3} \rightarrow \mathrm{R}_{2} \mathrm{CO}_{3}+\mathrm{H}_{2} \mathrm{O}, \\
\mathrm{R}_{2} \mathrm{CHOO}^{\circ}+\mathrm{R}_{3} \rightarrow \mathrm{R}_{2} \mathrm{COOR}_{3}, \\
\mathrm{R}_{2} \mathrm{CO}^{\circ}+\mathrm{R}_{3} \longrightarrow \mathrm{R}_{2} \mathrm{COOR}_{3} \\
\mathrm{HCO}^{\cdot}+\mathrm{R}_{3} \rightarrow \mathrm{R}_{4} \mathrm{OH}, \\
\mathrm{R}_{1}^{\cdot} \mathrm{C}^{\bullet} \mathrm{H}-\mathrm{R}_{3}^{\cdot}, \\
\mathrm{CHR}_{2}+\mathrm{R}_{3} \\
\stackrel{\mathrm{R}_{1} \mathrm{CH}}{\longrightarrow} \mathrm{CH}_{2} \mathrm{R}_{2}
\end{array}
$$
воздуха

Для высокотемпературных процессов, когда «время жизни» элементарного объема топливовоздушной смеси и озона с момента его образования в карбюраторе до момента сгорания в цилиндре не превышает $1 \cdot 10-2$ с, процесс газофазного озонолиза упрощается. Основываясь на современных представлениях о процессе горения предварительно перемешанной топливовоздушной смеси, по объему которой распространяется фронт пламени от точечного источника зажигания, можно априори охарактеризовать влияние дозирования озоно-воздушной смеси. Рост концентрации кислородсодержащих радикалов будет сказываться на направлении ряда последовательнопараллельных цепных реакций, которые протекают в кинетической области непосредственно перед фронтом пламени, обеспечивая более полное сгорание топлива.

Озонирование бензинов. При обработке топлива озоно-воздушной смесью:

- осуществляется гетерофазный хемосорбционный процесс взаимодействия высокоэффективного окислителя с несколькими реакционноспособными соединениями, находящимися в топливе. Процесс хемосорбции приводит к росту и равномерному распределению кислородсодержащих в объеме топлива;

- наблюдается растворение кислорода

- возможен унос легколетучих.

Влияние последнего фактора в опытах было минимизировано, так как легколетучие фракции бензина - это наиболее высокооктановые углеводороды Влияние микродозирования озоно-воздушной смеси в топливо связано в основном с первым фактором - хемосорбцией озона и реакциями озонолиза в жидкой фазе.

Анализ реакционной способности углеводородов можно осуществить по константе скорости реакции озонолиза К8 (л-моль-1. $\mathrm{c}^{-1}$ ) [4], которая равна:

для парафиновых углеводородов:

$1,5 \cdot 10-2 \ldots 0,7 \cdot 10^{\circ}$;

для нафтеновых углеводородов:

$3,4 \cdot 10-1 \ldots 5 \cdot 10-1$;

\section{озонировании бензинов}

(C) Г. С. Столяренко, 2019

DOI: $10.24025 / 2306-4412.4 .2019 .185448$ 
для олефиновых углеводородов:

$8,0 \cdot 104 \ldots 5 \cdot 105$.

Таким образом, озонолизу будут подвергаться в основном наиболее реакционноспособные олефиновые углеводороды. Гетерофазный озонолиз олефиновых углеводородов, так же как и для газофазного процесса, будет протекать по реакциям (1)-(11). При этом наблюдается синтез и накопление в бензине спиртов, альдегидов, эфиров и кетонов, а также незначительное количество карбоновых кислот. Кроме того, в результате синтеза кислородсодержащих органических соединений (октановые числа которых составляют $120 \pm 20)$ наблюдается рост октанового числа бензина. Снижение содержания олефиновых и замена их на кислородсодержащие органические соединения приводит к увеличению химической стабильности топлива, снижению его склонности образовывать отложения во впускной системе. Таким образом, присутствие в топливе альдегидов, спиртов и эфиров приводит к синтезу дополнительных радика- лов $\mathrm{H} \bullet, \mathrm{OH} \bullet, \mathrm{HO}, \mathrm{O} \bullet$ в каждом элементарном объеме топливовоздушной смеси в зоне, примыкающей к фронту пламени. Наблюдается улучшение подготовки топливовоздушной смеси к сжиганию, равномерность горения во всем фронте пламени, когда протекание всех радикальных процессов ускоряется в несколько раз, приобретает лавинный характер и кинетика уже перестает быть фактором, контролирующим процесс окисления углеводородов. Озоно-радикальная подготовка топлива должна привести к более полному протеканию окислительных реакций в гомогенной диффузной смеси.

Экспериментальная часть. Исследования по дозированию озона в двигатель проводились на стендовой установке (рисунок 1), состоящей из карбюраторного двигателя «Урал-353 А» и обкаточно-тормозного стенда КИ-2139 Б (таблица 1). Двигатель соединялся с тормозным генератором при помощи соединительной муфты.

Таблица 1 - Краткая техническая характеристика карбюраторного двигателя «Урал-353 А» и обкаточно-тормозного стенда КИ-2139 Б

\begin{tabular}{|c|c|}
\hline \multicolumn{2}{|c|}{ Краткая техническая характеристика } \\
\hline двигателя «Урал-353 А» & тормозного стенда \\
\hline Число цилиндров - 6 & Тип КИ-2139Б \\
\hline Диаметр поршня - 101,6 м & Тип электромашины АКБ 82-4 (балансирная, асин- \\
\hline Рабочий объем $-5,55$ л & хронная с фазным ротором) \\
\hline Ход поршня - 114,3 мм & Номинальная мощность -55 кВт \\
\hline Степень сжатия - 6,0 & Синхронная частота вращения ротора - 1500 об/мин \\
\hline $\begin{array}{l}\text { Максимальная мощность - } 69 \text { кВт (95 л.с.) } \\
\text { при } 2600 \text { об/мин }\end{array}$ & $\begin{array}{l}\text { Диапазон работы электромашины в режиме генера- } \\
\text { тора }-1700 \ldots 3000 \text { об/мин }\end{array}$ \\
\hline Карбюратор К82М & Максимальная тормозная мощность - 110 кВт \\
\hline Распределитель Р-32 & Напряжение тока питания - 380 В \\
\hline Генератор Г-250 & Тип нагрузочного реостата - жидкостный \\
\hline Аккумуляторная батарея 60T-190 & с охлаждением бака проточной водой \\
\hline & Емкость бака - 300 л \\
\hline
\end{tabular}

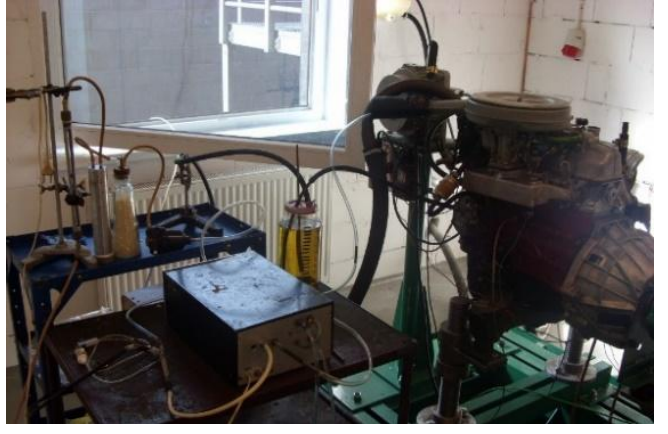

Рисунок 1 - Стендовая установка

Расход топлива двигателем замерялся путем прямого определения изменения массы топлива во времени. Расход воздуха, потребляемого двигателем, замеряли при по- мощи дифференциального манометра. Температуру отработавших газов измеряли при помощи термопары, устанавливаемой в выпускном трубопроводе на расстоянии 0,4 м от выхлопного патрубка и миллиамперметра. Обороты двигателя определяли с помощью тахометра, расположенного на щите нагрузочного стенда. В процессе эксперимента контролировали температуру масла в двигателе и температуру охлаждающей воды. Нагрузка задавалась при помощи нагрузочного реостата путем введения его ножейэлектродов в электролит. Основные параметры, характеризующие работу двигателя, определяли по следующим формулам: 
коэффициент избытка воздуха, где $1_{0}=15$,

$$
\alpha=\frac{G_{\mathrm{B}}}{l_{0} G_{\mathrm{T}}},
$$

мощность двигателя (л.с.; кВт)

$$
\begin{aligned}
& \mathrm{N}_{\mathrm{c}}=\frac{P \cdot n}{1000}, \\
& \mathrm{~N}_{\mathrm{c}}=\frac{P \cdot n}{1370},
\end{aligned}
$$

крутящий момент (кгм) $\mathrm{M}=\mathrm{P} \cdot 0,716$ ч,

удельный расход топлива $\mathrm{g}_{\mathrm{e}}=\frac{G_{\mathrm{T}} \cdot 10^{3}}{N_{c}}$.

Теплоту сгорания топливной смеси в двигателе определяли по количественному составу примесей в отработавших газах, анализ на озон проводили химическим и спектрофотометрическим методами, описанными ниже.

Изучение процесса дозирования озона в ДВС. Схема озонного инициирования работы карбюраторного ДВС включает две стадии: получение озоно-воздушной смеси и ее использование. Стадия получения озоновоздушной смеси состоит из блока генерирования озона, блока питания озонатора высоким напряжением и системы очистки и сушки воздуха.

Напряжение, подаваемое на электрод озонаторных трубок, вырабатывалось высоковольтным блоком питания. Он состоит из высоковольтного масляного трансформатора и автотрансформатора, которым можно регулировать напряжение, подаваемое на озонатор. Блок питания подсоединяется к сети переменного тока напряжением 220 В частотой 50 Гц. Максимальная потребляемая блоком питания мощность $-1,2$ кВт. Требуемая блоком озонаторов мощность не превышает 165 Вт.

Таблица 2 - Мощностные показатели работы блока озонаторов

\begin{tabular}{|l|l|l|l|l|}
\hline $\mathrm{U}$, кB & $\mathrm{I}, \mathrm{мA}$ & $\mathrm{N}, \mathrm{BT}$ & $\mathrm{C}_{03}, \%$ & $\mathrm{G}_{03}$, г/ч \\
\hline 5 & 3,2 & 16,0 & 0,5 & 4,0 \\
10 & 5 & 50 & 1,0 & 7,92 \\
15 & 11,0 & 165 & 1,45 & 11,5 \\
\hline
\end{tabular}

Данные таблицы 2, характеризующие показатели работы блока озонаторов, приведены для расхода воздуха $(5,5 \pm 0 Д)$ л мин $^{-1}$, который является оптимальным для данной системы генерирования озона. Давление воздуха на входе в систему составляло $(1,1-$ $-0,05) \cdot 10^{5}$ Па.

(C) Г. С. Столяренко, 2019

DOI: $10.24025 / 2306-4412.4 .2019 .185448$
Озоно-воздушная смесь подавалась или непосредственно в поток воздуха перед карбюратором, или в бензобак. В последнем случае отработанный воздух сбрасывался в дутье перед карбюратором.

Аналитический контроль. В отработавших газах двигателей внутреннего сгорания содержится более 250 компонентов. Основными из них, по которым можно определить полноту сгорания, являются оксид углерода, водород, метан и другие углеводороды, альдегиды, сажа и др. Для оценки токсичности выхлопных газов необходимо знать содержание 3,4-бенз(а)пирена, а также оксидов азота.

Перечисленные токсичные примеси (за исключением 3,4-бенз(а)пирена) определялись хроматографическим и линейноколориметрическим методами, содержание озона - иодометрическим и спектрофотометрическим методами. Анализ отработавших газов на содержание водорода, оксида углерода, формальдегида, метана и углеводородов $\mathrm{C}_{1}-\mathrm{C}_{5}$ проводился на хроматографе «Газохром 3101».

Применялись два вида колонок с различными газами-носителями:

1) колонка длиной 3 м, диаметром 3 мм из фторопласта; насадка - активированный уголь АР-3 с размером частиц: 0,6-0,8 мм; газноситель - воздух; температура $-20{ }^{\circ} \mathrm{C}$; расход - 60 мл/мин; детектор термохимический. Версия удерживания, с: водород - 20, азот и кислород - 80, оксид углерода -125 , метан - 140, этан - 155, пропан - 185, бутан - 280;

2) колонка длиной 1 м; газ-носитель гелий; расход - 80 мл/мин. Время удерживания, с: водород - 20, азот и кислород - 90, оксид углерода - 135, метан - 160, этан - 177. Углеводороды $\mathrm{C}_{5}-\mathrm{C}_{10}$ анализировались на хроматографе «Цвет 500». Предварительно они улавливались нелетучим растворителем в системе из двух последовательно соединенных поглотителей с пористым стеклянным барботажным распылителем. Расход контролировался по газовому счетчику. В качестве растворителя использовался додециловый или октиловый спирт. Объем газовой пробы составлял $(3 \pm 0,1)$ дм $^{3}$, расход газа при извлечении углеводородов - $(0,475 \pm 0,25)$ дм $^{3} /$ мин, объем растворителя $-10 \mathrm{~cm}^{3}$.

Условия анализа на хроматографе: колонка длиной 3 м, диаметром 3 мм из фторопласта; насадка - $5 \%$ силикона Е-30 на хро- 
матоне А; газ-носитель - гелий; расход 60 мл/мин; скорость роста температуры $80^{\circ} \mathrm{C} /$ мин; детектор - катарометр (I = $\left.120 \mathrm{MA}\right)$. Время удерживания, с: $\mathrm{C}_{5}-47, \mathrm{C}_{6}-75, \mathrm{C}_{7}-$ $135, \mathrm{C}_{8}-215, \mathrm{C}_{9}-345, \mathrm{C}_{10}-470, \mathrm{C}_{11}-595$.

В таблицах 3, 4 приведены основные результаты экспериментального изучения работы двигателя внутреннего сгорания при введении в карбюратор озоно-воздушной смеси. Влияние микродозирования озона изучалось при разных режимах работы двигателя: на холостом ходу и при малых нагрузках. Нагрузки 9,5 и 15,5 кгм соответствуют 10,7 и 16,5 кВт, что составляет 25-27 \% от номинальной мощности тормозного стенда (генератора). Повышение нагрузки свыше $30 \%$ оказалось нежелательным, так как вода в системе охлаждения реостата не должна изменять свою температуру для поддержания постоянной мощности (при остальных постоянных технологических и режимных параметpax) в течение опыта.

Таблица 3 - Влияние газофазного дозирования озона на содержание токсичных примесей в отработавших газах карбюраторного двигателя

\begin{tabular}{|c|c|c|c|c|c|c|c|c|}
\hline \multirow{2}{*}{\multicolumn{2}{|c|}{ Расход, кг/ч }} & \multirow{3}{*}{$\begin{array}{l}\text { Коэф-т } \\
\text { избыт- } \\
\text { ка воз- } \\
\text { духа, } \alpha\end{array}$} & \multirow{3}{*}{$\begin{array}{l}\text { Темпе- } \\
\text { paтypa, } \\
\text { t, }{ }^{0} \mathrm{C}\end{array}$} & \multirow{3}{*}{$\begin{array}{l}\text { Частота } \\
\text { враще- } \\
\text { ния, n, } \\
\text { об/мин }\end{array}$} & \multirow{3}{*}{$\begin{array}{l}\text { Расход } \\
\text { озона, } \\
\mathrm{g}_{\text {оз, }} \text { гчч }\end{array}$} & \multirow{2}{*}{\multicolumn{3}{|c|}{$\begin{array}{c}\text { Объемная доля токсичных приме- } \\
\text { сей, \% до (после) озонирования }\end{array}$}} \\
\hline & & & & & & & & \\
\hline & & & & & & $\begin{array}{l}\text { углерода } \\
\mathrm{C}_{\mathrm{co}}\end{array}$ & $\begin{array}{l}\text { азота } \\
\mathrm{C}_{\mathrm{NOx}} \cdot 10^{-3}\end{array}$ & $\begin{array}{l}\text { родов } \\
\mathrm{C}_{\mathrm{CnHm}} \cdot 10^{-3}\end{array}$ \\
\hline $\begin{array}{l}\text { возду- } \\
\text { ха, } \mathrm{G}_{\mathrm{B}}\end{array}$ & $\begin{array}{l}\text { топли- } \\
\text { ва, } \mathrm{G}_{\mathrm{T}}\end{array}$ & & & & & & & \\
\hline 53,0 & 2,4 & 1,47 & 486 & 1600 & 1,06 & $0,9(0,5)$ & $18,5(17,0)$ & $0,21(0,21)$ \\
\hline 47,4 & 3,3 & 0,96 & 389 & 1440 & 1,09 & $5,5(4,9)$ & $10(9,5)$ & $0,12(0,10)$ \\
\hline 42,4 & 3,4 & 0,83 & 367 & 1480 & 1,06 & $6,5(5,3)$ & $8,5(8)$ & $0,16(0,13)$ \\
\hline 52,0 & 3,6 & 0,96 & 500 & 1660 & 1,08 & $5,9(5,0)$ & $10(10)$ & $0,14(0,13)$ \\
\hline 42,4 & 3,6 & 0,79 & 400 & 1540 & 1,06 & $6,0(5,0)$ & $7,5(7)$ & $0,16(0,14)$ \\
\hline 42,4 & 3,3 & 0,86 & 414 & 1500 & 1,06 & $6,0(5,0)$ & $7,5(7,5)$ & $0,15(0,12)$ \\
\hline 42,4 & 3,2 & 1,17 & 403 & 1410 & 1,08 & $2,8(1,5)$ & $21,5(21,3)$ & $0,14(0,14)$ \\
\hline 42,6 & 4,4 & 0,65 & 319 & 1340 & 1,06 & $8,0(6,3)$ & $0,5(0,5)$ & $0,22(0,16)$ \\
\hline 42,5 & 4,2 & 0,67 & 219 & 1200 & 1,06 & $8,0(6,4)$ & $0,6(0,5)$ & $0,21(0,19)$ \\
\hline 80,4 & 2,7 & 1,29 & 569 & 1640 & 1,02 & $0,13(0,08)$ & $17(15)$ & $0,18(0,17)$ \\
\hline 67,1 & 5,1 & 1,20 & 504 & 1430 & 1,07 & $0,15(0,09)$ & $5,5(16)$ & $0,14(0,12)$ \\
\hline 73,5 & 3,9 & 1,26 & 536 & 1440 & 1,02 & $0,08(0,08)$ & $55(55)$ & $-(-)$ \\
\hline 73,5 & 5,04 & 0,97 & 540 & 1420 & 1,10 & $0,6(0,4)$ & $47(53)$ & $0,09(0,06)$ \\
\hline 79,4 & 51 & 1,0 & 580 & 1680 & 1,06 & $0,3(0,1)$ & $55(59)$ & $0,08(006)$ \\
\hline 76,5 & 5,1 & 1,0 & 554 & 1540 & 1,10 & $0,28(0,10)$ & $60(60)$ & $0,08(0,05)$ \\
\hline 60,0 & 5,7 & 0,7 & 403 & 1300 & 1,06 & $1,6(0,7)$ & $5,5(7,5)$ & $0,13(0,10)$ \\
\hline 60,0 & 5,7 & 0,7 & 440 & 1300 & 1,06 & $1,4(0,7)$ & $5,0(7,5)$ & $0,13(0,10)$ \\
\hline 60,0 & 6,0 & 0,67 & 378 & 1300 & 1,10 & $2,1(1,1)$ & $2,0(2,4)$ & $0,15(0,14)$ \\
\hline 67,4 & 6,4 & 0,77 & 434 & 1330 & 1,10 & $1,5(0,4)$ & $2,0(2,0)$ & $0,13(0,11)$ \\
\hline 94,9 & 6,0 & 1,05 & 583 & 1460 & 1,01 & $0,25(0,1)$ & $52(52)$ & $-(-)$ \\
\hline 101,7 & 6,0 & 1,13 & 590 & 1520 & 1,10 & $0,2(0,05)$ & $57(57)$ & $0,12(0,09)$ \\
\hline 101,7 & 7,2 & 0,94 & 605 & 1600 & 1,01 & $0,4(0,2)$ & $-(30)$ & $0,10(0,08)$ \\
\hline 84,9 & 8,4 & 0,67 & 468 & 1420 & 1,02 & $1,4(1,0)$ & $5,0(7,5)$ & $0,18(0,16)$ \\
\hline 84,9 & 8,7 & 0,65 & 468 & 1400 & 1,10 & $1,5(0,7)$ & $7,5(7,5)$ & $0,18(0,16)$ \\
\hline 95,1 & 8,7 & 0,73 & 440 & 1420 & 1,02 & $1,4(1,2)$ & $4,0(7,0)$ & $0,17(0,13)$ \\
\hline
\end{tabular}


Таблица 4 - Влияние газофазного дозирования озона на режимные параметры работы карбюраторного двигателя на холостом ходу

\begin{tabular}{|l|l|l|l|l|l|l|l|l|l|}
\hline$\alpha$ & $\begin{array}{l}\mathrm{g}_{\text {оз }} / \mathrm{G}_{\mathrm{T}}, \\
\text { ГкГ }\end{array}$ & $\begin{array}{l}\frac{\mathrm{g}_{\text {о3 }}}{\mathrm{G}_{\mathrm{T}}+\mathrm{G}_{\mathrm{s}}} \\
\text { Г/кг }\end{array}$ & $\begin{array}{l}\mathrm{n}, \\
\text { об/мин }\end{array}$ & $\Delta \mathrm{n}$ & $\mathrm{t},{ }^{0} \mathrm{C}$ & $\Delta \mathrm{t}$ & $\begin{array}{l}\Delta \mathrm{C}_{\mathrm{Co} 3}, \\
\%\end{array}$ & $\begin{array}{l}\Delta \mathrm{C}_{\mathrm{NOx}}, \\
\% \cdot 10^{3}\end{array}$ & $\begin{array}{l}\Delta \mathrm{C}_{\mathrm{CnHm}}, \\
\% \cdot 10^{3}\end{array}$ \\
\hline 1,47 & 0,44 & 0,020 & 1600 & +40 & 486 & +7 & $-0,4$ & $-1,5$ & - \\
\hline 0,96 & 0,32 & 0,022 & 1400 & +10 & 389 & +11 & $-0,6$ & $-0,5$ & - \\
\hline 0,83 & 0,31 & 0,024 & 1480 & +10 & 367 & +20 & $-1,2$ & $-0,5$ & - \\
\hline 0,96 & 0,29 & 0,020 & 1660 & 0 & 500 & -2 & $-0,9$ & 0 & - \\
\hline 0,79 & 0,29 & 0,024 & 1540 & +10 & 400 & +14 & $-1,0$ & $-0,5$ & - \\
\hline 0,86 & 0,32 & 0,024 & 1500 & +20 & 414 & 0 & $-1,0$ & 0 & - \\
\hline 1,17 & 0,25 & 0,024 & 1410 & 0 & 396 & +7 & $-1,3$ & $-0,2$ & $-0,02$ \\
\hline 0,67 & 0,25 & 0,024 & 1200 & 0 & 219 & 0 & $-1,6$ & $-0,1$ & $-0,02$ \\
\hline 0,65 & 0,24 & 0,023 & 1340 & 0 & 319 & 0 & $-1,7$ & 0 & $-0,06$ \\
\hline
\end{tabular}

Однако достигнутые режимы нагрузки и полученные экспериментальные данные дают полную характеристику влияния озона на работу двигателя. Единичные определения содержания в отработавших газах бенз(а)пирена, альдегидов и сажи показали, что их количество снижается соответственно на $20 \div 30,15 \div 40$ и $10 \div 80 \%$.
В таблице 5 приведены основные зависимости, обусловленные влиянием жидкофазного озонирования, т. е. при работе двигателя на озонированном этилированном бензине. Изучаемые параметры оставались те же, что и при газофазном озонировании. Количество озона, растворяемого в бензине, составляло $0 \div 1,2$ г/кг топлива.

Таблица 5 - Изменение характеристик работы двигателя при работе на озонированном бензине (от различной дозы озона)

\begin{tabular}{|c|c|c|c|c|c|}
\hline \multirow[t]{2}{*}{ Характеристика } & \multicolumn{5}{|c|}{ Доза озона, г/дм ${ }^{3}$} \\
\hline & 0 & 0,345 & 0,690 & 1,035 & 0 \\
\hline Частота вращения, об/мин & 1700 & 1700 & 1680 & 1670 & 1700 \\
\hline Температура отработавших газов, & 445 & $44^{\prime} 6$ & 435 & 440 & 455 \\
\hline Коэффициент избытка воздуха & 1,13 & 1,20 & 1,27 & 1,18 & 1,14 \\
\hline Расход топлива, кг/ч & 3,54 & 3,26 & 3,15 & 3,40 & 3,50 \\
\hline $\begin{array}{c}\text { Объемная доля, \%: } \\
\text { оксида углерода } \\
\text { оксида азота } \\
\text { углеводородов }\end{array}$ & $\begin{array}{c}0,24 \\
0,0014 \\
0,08\end{array}$ & $\begin{array}{c}0,20 \\
0,0010 \\
0,08\end{array}$ & $\begin{array}{c}0,05 \\
0,0010 \\
0,05\end{array}$ & $\begin{array}{c}0,11 \\
0,0010 \\
0,06\end{array}$ & $\begin{array}{c}0,25 \\
0,0014 \\
0,07\end{array}$ \\
\hline
\end{tabular}

Использование озона как при газофазном, так и при жидкофазном дозировании увеличивает окислительную способность дутья за счет роста кислородсодержащих радикалов при химической подготовке топлива к воспламенению, облегчая эту подготовку, что дает положительные результаты. Рассмотрим влияние озона на изменение содержания токсичных примесей в отработавших газах.

Снижение содержания оксида углерода (II). В соответствии с предложенными механизмами окисления углеводородов в пламе- ни их термодеструкция осуществляется всегда через оксид углерода (II), т. е. причина образования СО - естественное состояние любого пламени (особенно в предпламенный период). Основной причиной появления СО являются реакции термодеструкции радикала $\mathrm{CHO}^{\circ}$ и его взаимодействия с другими радикалами. В предпламенный период существует конкуренция между термическим распадом радикала $\mathrm{CHO}^{\circ}$ и его реакциями с $\mathrm{H}^{*}, \mathrm{O}^{\circ}, \mathrm{OH}^{*}$ и $\mathrm{O}_{2}$.

Сравнительный анализ кинетических данных реакций (12) показывает, что СО син- 
тезируется при высокоскоростных радикальных процессах из СНО на 90 \%, так как радикал $\mathrm{CHO}^{\circ}$ может окисляться и до $\mathrm{CO}_{2}$ :

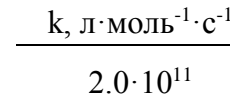

$$
\begin{aligned}
& \mathrm{CHO}^{\bullet}+\mathrm{H}^{\cdot} \rightarrow \mathrm{CO}+\mathrm{H}_{2} \\
& \mathrm{CHO}^{\circ}+\mathrm{O}^{*} \rightarrow \mathrm{CO}+{ }^{\circ} \mathrm{OH} \\
& 3.0 \cdot 10^{10} \\
& \mathrm{CHO}^{*}+\mathrm{OH}^{\cdot} \rightarrow \mathrm{CO}+\mathrm{H}_{2} \mathrm{O} \\
& 3,0 \cdot 10^{10} \\
& \mathrm{CHO}^{\bullet}+\mathrm{O}_{2} \rightarrow \mathrm{CO}+\mathrm{HO}_{2}^{\bullet} \\
& \mathrm{CHO}^{*}+\mathrm{M} \rightarrow \mathrm{CO}+\mathrm{H}^{+}+\mathrm{M} \\
& 3,0 \cdot 10^{9} \\
& 10^{7} \div 10^{9} \\
& \mathrm{CHO}^{\bullet}+\mathrm{O}^{\cdot} \rightarrow \mathrm{CO}_{2}+\mathrm{H}^{\bullet}\left(\mathrm{\kappa}^{3}, 0 \cdot 10^{10} \text { л } \cdot \text { моль }{ }^{-1} \cdot \mathrm{c}^{-1}\right) \text {. }
\end{aligned}
$$

Механизм дожигания СО при озонировании основывается на следующих химических реакциях:

$$
\begin{array}{ll} 
& \mathrm{k}, \text { л } \cdot \text { моль } \\
\cline { 2 - 2 } \mathrm{CO}+\mathrm{OH}^{-1} \rightarrow \mathrm{cO}_{2}+\mathrm{H}^{\cdot} & 5.8 \cdot 10^{6} \\
\mathrm{H}^{\cdot}+\mathrm{O}_{2} \rightarrow \mathrm{HO}_{2}^{\cdot} & 1,5 \cdot 10^{10} \\
\mathrm{CO}+\mathrm{HO}_{2}^{\cdot} \rightarrow \mathrm{CO}_{2}+\mathrm{OH} & 1,5 \cdot 10^{6}
\end{array}
$$

Вторичные процессы дожигания оксида углерода (II) медленнее реакций синтеза. Очень полезна реакция с радикалом кислорода, но она может протекать только при специфических условиях, например, в сухих пламенах СО. Даже незначительное содержание водородсодержащих молекул углеводорода полностью подавляет ее. Таким образом, наблюдаемое стабильное снижение содержания оксида углерода (II) при разных режимах работы двигателя и способах подачи озоновоздушной смеси необходимо связать только с ростом концентраций $\mathrm{OH}^{*}$ и $\mathrm{HO}_{2}^{*}$. Причем влияние радикальной реакции с $\mathrm{HO}_{2}{ }^{\circ}$ наиболее реально, так как устойчивость радикала возрастает при повышенных температурах.

Другое объяснение полному подавлению образования СО при работе двигателя на обедненных смесях, когда замена обычного бензина озонированным приводит к постоянному снижению объемной доли СО на 0,5-

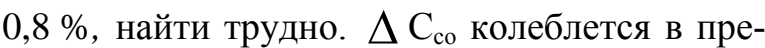
делах от 0,3 до 2,5 \% при дозах озона до 0,6 г на 1 кг топлива (газофазное дозирование). При жидкофазном озонировании ни в одном из опытов не наблюдалось повышение содержания оксида углерода (II) при дозах озона на

(C) Г. С. Столяренко, 2019

DOI: $10.24025 / 2306-4412.4 .2019 .185448$ порядок ниже. На многих режимах достигнуто нулевое содержание СО в отработанных газах ДВС.

Влияние озона на содержание сажи в отработавших газах. Причиной образования сажи при работе двигателя на сильно обедненных смесях являются реакции дегидрогенизации и образования ацетилена. В связи с тем, что в бензине всегда присутствуют этиленовые и ароматические углеводороды, промежуточные концентрации ацетилена высоки даже при работе двигателя на обедненных смесях.

При сгорании обогащенных топливовоздушных смесей выход по реакции дегидрогенизации еще более возрастает, сгорание протекает с детонацией при недостатке кислорода, что приводит к росту содержания сажи в отработавших газах.

И в том, и в другом случае в процессе дегидратации этиленовых углеводородов в элементарном объеме наблюдается неравномерность распределения окислителя, что приводит к тушению пламени, а значит, к крекингу углеводородного топлива.

По другому механизму сажеобразования зародышем крекинга топлива считаются атомы водорода, которые при дефиците кислорода ускоряют процессы дегидрогенизации углеводородов.

При использовании озонированного топлива, а также при дозировании озона в дутье частично устраняются все эти причины: вопервых, при озонировании снижается содержание олефиновых углеводородов; во-вторых, равномерное распределение микродоз озона и кислорода по всему реакционному объему топливовоздушной смеси препятствует протеканию реакций по цепи $\mathrm{C}_{2} \mathrm{H}_{6} \rightarrow \mathrm{C}_{2} \mathrm{H}_{4} \rightarrow$ $\mathrm{C}_{2} \mathrm{H}_{2} \rightarrow \mathrm{C}$.

И, наконец, вновь синтезируемые радикалы $\mathrm{HO}_{2}$, а также альдегиды, кетоны и эфиры регулируют текущую концентрацию радикалов водорода:

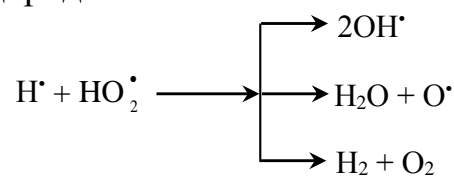

Таким образом, вместо очага сажеобразования возникает дополнительный элементарный объем с высокой окислительной способностью, позволяющий продолжить окислительные процессы углеводородных радикалов. Максимально низкое содержание сажи в отработавших газах - не более 0,02 г/ $\mathrm{M}^{3}-$ дос- 
тигнуто при низких концентрациях оксида углерода (II). При росте объемной доли СО выше $0,5 \%$ озонирование практически не сказывалось на подавлении сажеобразования.

Содержание оксидов азота. Подавление образования оксидов азота ожидалось в связи с ростом текущей концентрации радикалов $\mathrm{OH}^{*}$ и $\mathrm{HO}_{2}{ }^{\circ}$, образующихся по реакциям:

$$
\begin{array}{r}
\mathrm{O}^{\circ}+\mathrm{HO}_{2}{ }^{\circ} \rightarrow 2 \mathrm{OH}^{*}, \\
\mathrm{O}^{*}+\mathrm{OH}^{\cdot} \rightarrow \mathrm{HO}_{2} .
\end{array}
$$

При газофазном дозировании озона в обедненные смеси в $30 \%$ опытов при горении наблюдался незначительный рост содержания оксидов азота (на 10-20\%). В остальных опытах отмечено постоянство данного параметра.

Повышение содержания $\mathrm{NO}_{\mathrm{x}}$ объясняется дополнительным связыванием атмосферного азота атомарным кислородом.

Незначительное снижение содержания оксидов азота (в среднем на $10-20 \%$ ) в опытах по жидкофазному дозированию озона, в основном, объясняется снижением температуры горения. Так, постоянство частоты вращения и мощности двигателя достигалось при горении топлива, в котором синтезировались спирты, альдегиды, эфиры (соединений с повышенным октановым числом). Дозирование озона в жидкую фазу ни в одном из опытов не приводило к росту содержания оксидов азота в отработавших газах.

Таким образом, газофазное озонирование незначительно влияет на содержание оксидов азота в отработавших газах, в то время как жидкофазное - дает устойчивый положительный эффект.

Изменение режимных факторов при работе двигателя. Основной задачей исследования являлись проблемы экологического плана. Однако интерес представляют и побочные результаты действия высокоэффективного окислителя.

Использование в качестве топлива озонированного бензина обеспечивает устойчивую работу двигателя при раннем и позднем зажигании, звук работающего двигателя становится более басовитым, при оптимальной дозе озона нет детонации в случае горения низкооктанового топлива, двигатель легко запускается в холодное время года. Все эти явления объясняются синтезом альдегидов и спиртов, а главное, эфиров в объеме бензина.

Данные соединения обладают высокой детонационной стойкостью, причем снижает- ся неравномерность распределения детонационной стойкости бензина по фракциям, падает его склонность к нагарообразованию. Октановое число бензина при увеличении дозы озона проходит через максимум в области $0,6+0,8$ г окислителя на 1 кг топлива. Максимум повышения составляет 6-6,5 единицы.

Усредненные данные по газофазному дозированию озона свидетельствуют о росте температуры на $3-14{ }^{0} \mathrm{C}$; по жидкофазному - о ее снижении на $10-15{ }^{\circ} \mathrm{C}$. При постоянной мощности двигателя и расходе топлива частота вращения возрастает на 20-40 об/мин.

При постоянных частоте вращения, расходе топлива и воздуха отмечено незначительное повышение мощности двигателя (на 3-3,5 \%) при газофазном дозировании озона. Во всех опытах по газофазному дозированию озона достигнута экономия топлива. В среднем при работе двигателя на холостом ходу и под нагрузками 9,5 кгм (10,7 кВТ) и 15,5 кгм $(16,5$ кВт) она составляла соответственно 3,5 ; 2,11 и $1,75 \%$. Стабильная экономия (от $3,5 \%$ до $11 \%$ ) наблюдалась при работе двигателя на озонированном бензине. Небезынтересен и тот факт, что получены постоянные характеристики двигателя при одном и том же удельном расходе топлива, но в зоне более высоких коэффициентов избытка воздуха.

Эти результаты можно объяснить только тем, что озоновая присадка (как при газофазном, так и при жидкофазном дозировании озона) выполняет антидетонационную роль, разрушая пероксидные соединения, которые образуются в предпламенный период в камере сгорания, увеличивая эффективность и полноту горения топлива.

Цепным механизмом (17) объясняется макровоздействие озона при его микродобавках в зону горения. Лишь ассимиляцией радикалов 'ОН и $\mathrm{HO}_{2}$ ' можно объяснить неполное сгорание и при озонном методе интенсификации процесса горения.

$$
\begin{gathered}
\mathrm{ROOH}+\mathrm{HO}_{2}{ }^{\circ} \rightarrow \mathrm{ROH}+2^{\circ} \mathrm{OH}, \\
\mathrm{ROOH}+{ }^{\circ} \mathrm{OH} \rightarrow \mathrm{ROH}+\mathrm{HO}_{2}^{\circ} .
\end{gathered}
$$

\section{Выводы:}

1. Согласно современным представлениям о процессе горения топливовоздушной смеси, все токсичные соединения в отработавших газах двигателя внутреннего сгорания образуются в результате неполного сгорания топлива. Проникновение озона в структуру углеводородов бензина позволяет равномерно 
распределить окислитель в объеме топливовоздушной смеси, что приводит к более полному ее сгоранию. Этим объясняется снижение концентрации токсичных соединений в отработанных газах.

2. Использование озонированного бензина улучшает такой эксплуатационный параметр двигателя, как экономичность (экономия топлива до 7 \%) и повышает его мощность.

3. Озоновая добавка в топливо за счет образования в объеме топливовоздушной смеси радикалов $\mathrm{HO} \bullet ; \mathrm{HO}^{2} \bullet ; \mathrm{RO}^{2} \cdot$ разрушает пероксидные соединения, которые являются главным источником детонационного сгорания бензина.

4. Эффективная озонная подготовка топливовоздушной смеси в предпламенный период положительно влияет не только на снижение токсичности выбросов, но и на режимные параметры работы двигателя.

\section{Список литературы}

[1] В. А. Якоби, Химия элементоорганических соединений: сб. Горький: ГТУ, 1979, c. 104-106.

[2] С. Д. Разумовский, и Г. Е. Заиков, Изв. АН СССР. Сер. Хим., с. 322, 1971.

[3] В. Ф Кожинов, Озонирование воды. Москва: Стройиздат, 1974.

[4] Ю. Окамото, "Генератор озона для двигателя внутреннего сгорания", Евр. патент МКИ СОIВ 13/11. № 83/04243, Авг. 24, 1982.

[5] А. Театтик, "Устройство по дозированию озонированного воздуха в двигатель внутреннего сгорания", Патент ФРГ МКИ F 02 М 25/10. № 2540990, 1997.

[6] Г. С. Столяренко, "Способ питания двигателя внутреннего сгорания", А.c. СССР МКИ F 02 M 25/10. № 1240943, Март 11, 1984.

[7] Г. С. Столяренко, "Інтенсифікація процесу горіння рідкого палива озоновим методом", Експрес-новини: наука, техніка, виробниитво, № 7-8, с. 8-10, 1998.

[8] Г. С. Столяренко, та А. В. Громико, "Інтенсифікація процессу горіння бензина у ДВЗ", Хімічна промисловість Украӥни, № 1, с. 23, 1996.

[9] Г. С. Столяренко и др., "Диэлектрик с микрорельефом на его поверхности преимущественно для озонаторов", Патент
России МКИ В ОI D 53/16. № 2016840, Февр. 26, 1991.

[10] Г. С. Столяренко и др., "Устройство для электронно-лучевой обработки объектов", Патент России МКИ В ОI D 53/16. № 2023746, Февр. 26, 1991.

[11] Г. С. Столяренко и др., "Способ изготовления микрорельефа на диэлектрической поверхности", Патент России МКИ В ОІ D 55/16. № 1819250, Февр. 26, 1991.

[12] Г. С. Столяренко та ін., "Пристрій для живлення двигуна внутрішнього згорання озонованим паливом", Патент Украӥни MKI F 02 M 25/10. № 22004, Січ. 09, 2003.

\section{References}

[1] V. A. Jacobi, Chemistry of Organoelement Compounds: proc., Gorky: GTU, 1979, pp. 104-106 [in Russian].

[2] S. D. Razumovsky, and G. E. Zaikov, Izv. USSR Academy of Sciences. Ser. Chem., p. 322, 1971 [in Russian].

[3] V. F. Kozhinov, Water ozonation. Moscow: Stroyizdat, 1974 [in Russian].

[4] Yu. Okamoto, "Ozone generator for internal combustion engine", Europ. Patent MKI SOIV 13/11. No. 83/04243, Aug. 24, 1982. [in Russian].

[5] A. Teattic, "The device for dosing ozonated air into the internal combustion engine", Germany Patent MKIFO2 M 25/10. No. 2540990, 1997 [in Russian].

[6] G. S. Stolyarenko, "The method of the question of the internal combustion engine", USSR certificate of authorship MKI F $02 \mathrm{M}$ 25/10. No. 1240943, March 11, 1984.

[7] H. S. Stolyarenko, "Intensification of the process of combustion of liquid fuel with ozone", Ekspres-novyny: nauka, tekhnika, vyrobnytstvo, no. 7-8, pp. 8-10, 1998 [in Ukrainian].

[8] H. S. Stolyarenko, and A. V. Gromyko, "Intensification of gasoline combustion process in ICE", Khimichna promyslovist Ukrainy, no. 1, p. 23, 1996 [in Ukrainian].

[9] G. S. Stolyarenko et al., "A dielectric with a microrelief on its surface mainly for ozonizers", Rus. Patent MKIVOID 53/16. No. 2016840, Feb. 26, 1991 [in Russian].

[10] G. S. Stolyarenko et al., "Device for electron-beam processing of objects", Rus. Pa- 
tent MKI B OI D 53/16. No. 2023746, Feb. 26, 1991 [in Russian].

[11] G. S. Stolyarenko et al., "A method of making microrelief on a dielectric surface", Rus. Patent MKI B OI D 55/16. No. 1819250, Feb. 26, 1991 [in Russian].
[12] G. S. Stolyarenko et al., "The device for power supply of the internal combustion engine with ozone fuel", Ukr. Patent MKI F 02 M 25/10. No. 22004, Jan. 09, 2003 [in Ukrainian].

H. S. Stolyarenko, Dr. Tech. Sc., professor

e-mail: radikal@ukr.net

Cherkasy State Technological University

Shevchenko blvd, 460, Cherkasy, 18006, Ukraine

\section{THEORETICAL BASES OF THE OZONING PROCESS OF LIQUID FUEL AND STUDY OF THE INFLUENCE OF OZONE SMALL DOSES ON THE WORK OF CARBURATOR INTERNAL COMBUSTION ENGINE (ICE)}

Theoretical bases and chemistry of ozonation of the fuel during the introduction of the oxidant in both the gas and liquid phases are considered. The mechanisms of chemical processes of intensification of fuel combustion, suppression of the formation of toxic compounds during ozone dosing are presented. The radical-ion mechanism of the chain reactions of the oxidant macroactivity at its microadditives is shown. The possibility of saving liquid fuel has been established. The experimental verification of the effect of ozone small doses on the process of combustion of gasoline in internal combustion engines is presented.

Due to the fact that this reaction mechanism is very well studied, this makes it possible to theoretically trace the effect of synthesized compounds. A number of experiments have been carried out, the results of which are presented. The brief technical characteristics of the engine and brake stand are named. Engine fuel consumption has been measured by directly determining the change in fuel mass over time. The flow rate of air consumed by the engine has been measured using a differential pressure gauge. The temperature of the exhaust gases has been measured using a thermocouple. Theoretical foundations of the analytical control of the process, the reduction of carbon monoxide, the effect of ozone on the soot content in the exhaust gases, the change in operational factors during engine operation are described. The use of ozonized gasoline improves such an engine operating parameter as efficiency (fuel economy up to $7 \%$ ) and increases its power. Ozone additive in fuel due to the formation of $\mathrm{HO}^{\circ}$ radicals in the volume of the fuel-air mixture, radicals $\mathrm{HO}^{\circ} ; \mathrm{HO}_{2} ; \mathrm{RO}_{2}{ }^{\circ}$ destroys peroxide compounds, which are the main source of detonation combustion of gasoline. The effective ozone preparation of the fuel-air mixture in the pre-flame period positively affects not only the reduction of toxicity of emissions, but also the operating parameters of the engine.

Keywords: ozonolysis of olefinic hydrocarbons, preparation of fuel for combustion, burning of ozonated gasoline.

Стаття надійшла 16.11.2019

Прийнято 01.12.2019

(C) Г. С. Столяренко, 2019

DOI: $10.24025 / 2306-4412.4 .2019 .185448$ 